\title{
PCR - Based Detection of Microcystin and Nodularin in both Freshwater and Bloom in Tigris River
}

\author{
Ibrahim J. Abed ${ }^{1 *}$, Ghusoon A. Abdulhasan ${ }^{1}$, Hu Han ${ }^{2}$, Zhang Juyuan ${ }^{3}$, \\ Shaoran Zhang ${ }^{2}$ and Qigai $\mathrm{He}^{2}$. \\ ${ }^{1}$ Department of Biology, University of Baghdad, Al-Jaderiyah 10070, Baghdad-Iraq. \\ ${ }^{2}$ State Key Laboratory of Agricultural Microbiology, Division of Animal Infectious Diseases, \\ College of Veterinary Medicine, Huazhong Agricultural University, \\ Wuhan430070, Hubei, P.R., China. \\ ${ }^{3}$ Institute of Hydrobiology, Chinese Academy of Sciences, Wuhan 430072, China. \\ * Corresponding Author: ibrahimabed95@yahoo.com
}

\begin{abstract}
Cyanobacterial blooms have a range of social, environmental and economic impacts due to their content of secondary metabolites involving toxins. Microcystins (MCs) is one of the cyanotoxins found in freshwater ecosystems. This study was aimed to adopt a rapid technique for determining the microcystin in blooms and freshwater by the detection of phycocyanin operon of cyanobacteria using PC $\beta \mathrm{F}$ and $\mathrm{PC} \alpha \mathrm{R}$ primers as well as $m c y E$ gene encoding to microcystin/ nodularin using HEP primers. The molecular results showed that phycocyanin operon and $m c y E$ gene were disclosed in the freshwater and bloom of samples at the studied sites. In conclusion, The PCR assay used in this study was helpful and rapid, in particular when the target organism concentration in the freshwater sample is very low. [DOI: 10.22401/ANJS.21.4.08]
\end{abstract}

Keywords: Microcystin, cyanobacteria, Iraqi freshwater, bloom, PCR.

\section{Introduction}

Increases in the duration and prevalence of harmful cyanobacterial blooms in freshwater may due to changes in environmental conditions such as increment of global temperature and dropped off water quality [1], [2].

Harmful blooms of cyanobacteria represent a threat to human and environmental health and also resulting in unfavorable economic impacts. Exposure to secondary toxic metabolites (cyanotoxins) formed by cyanobacteria during skin contact and consuming of water leads to human and animal illness and in some cases lead to death [3]. However, cases of human intoxications have been reported following exposure to Microcystis and Plantothrix blooms [4]. The famous case of human exposure took place in 1996 in Caruaru, Brazil when 131 people were incurred to microcystin during dialysis, 116 of them were ill and 52 people died [5].

In turn this has led to the World Health Organisation (WHO) recommendation of a drinking water guideline value for microcystin-LR, of $1 \mu \mathrm{g} / \mathrm{L}$ for lifelong consumption [6].
Nodularia spumigena is a toxic, filamentous cyanobacterium produce nodularin occurring in brackish waters worldwide, but most extensive blooms are reported in estuaries, lagoons and inland waters of Australia and New Zealand [7]. Nodularin production is primarily found under brackish conditions. Recent reports of a nodularin producing Nodularia sp. In a fresh water lake in Turkey [8].

In the last few decades, reports on harmful blooms of cyanobacteria in the world have heightened. Global warming could participate to a further rise in the production of harmful blooms of cyanobacteria. Therefore, there is an increasing interest in the last years because these blooms decrease water quality subsequently affecting agricultural and probability contaminating drinking water supplies [9].

Eutrification via agricultural, industrial and the sewage current that protected the growth of cyanobacteria as well as production of mycrocystin, usually affect Tigris River particularly in Baghdad. This study was aimed to tool up a rapid technique for determining the microcystin in blooms and freshwater by 
the detection of phycocyanin operon of cyanobacteria as well as $m c y E$ gene encoding to microcystin by PCR assay.

\section{Materials and Methods Collection of samples}

The studied area involved three sites on Tigris River / Baghdad city with one sample per site; site 1 was located in Sader Al-Qanat area at north of Baghdad, site 2 in Al-Jadiryia area and site 3 located at south side in AlZafrania area. During 2014, samples from summer months (freshwater and bloom) were collected from mentioned sites. Samples (500 $\mathrm{ml}$ ) from freshwater were concentrated by centrifuged and the pellets were collected to obtain one $\mathrm{ml}$ which utilized for the molecular methods.

\section{DNA isolation}

Isolation of DNA was done according to [10] from about $200 \mathrm{mg}$ wet weight from the bloom samples and also from concentrated freshwater samples $(1 \mathrm{ml})$ as well as from Microcystis flos-aquqae ,Anabaena sp. and Microcystis aeruginosa which isolated from site 1,2 and 3,respectively. These isolates used as positive control to detect the genes under study in environmental samples. Lysis buffer $(600 \mu \mathrm{l})$ that contained $20 \mathrm{mM}$ EDTA, $1 \%$ SDS, $800 \mathrm{mM}$ ammonium acetate and 100 $\mathrm{mM}$ Tris- $\mathrm{HCl}(\mathrm{pH}$ 7.4) was added to samples. The mixture combined and incubated at $65^{\circ} \mathrm{C}$ for $2 \mathrm{~h}$, then placed in ice for $10 \mathrm{~min}$ to cool the extract. The mixture was centrifuged at $12,000 \mathrm{~g}$ for $10 \mathrm{~min}$ to remove cell debris. DNA was precipitated by addition of 1 vol. of isopropanol and 0.1 vol. of $4 \mathrm{M}$ ammonium acetate for $15 \mathrm{~min}$ at cooling temperature $\left(4^{\circ} \mathrm{C}\right)$ then DNA was collected by centrifugation with the same conditions mentioned above and washed with ethanol (70\%). The isolated DNA was suspended in TE buffer.

\section{Amplification of $c p c B-I G S-c p c A$ region and $m y c E$ gene}

Two sets of primers were used in PCR reactions. The first one was PC $\beta F \quad\left(5^{\prime}\right.$ GGCTGCTTGTTTACGCGACA-3') and PC $\alpha \mathrm{R}$ (5'-CCAGTACCACCAGCAACTAA$\left.3^{\prime}\right)$ [11] for amplifying the region ( $c p c B-I G S$ $c p c A$ ) of phycocyanin operon and the other one was the HEPF (5'-TTTGGGGTT AACTTTTTTGGGCATAGTC-3') and HEPR (5'-AATTCTTGAGGCTGTAAATCGGGTT T-3') [12] utilized for detection of $m c y E$ gene of the microcystin synthetase. The total volume of PCR mixture was $20 \mu$ involved PCR premix (Accupower, Bioneer), primer (1picomole) and DNA (100 ng) then the mixture was completed with sterile deionized distilled water. Negative control was prepared by adding all PCR mixture except DNA was replaced with distilled water. One programme of PCR included one cycle at $95^{\circ} \mathrm{C}, 2 \mathrm{~min} ; 35$ cycles at $95^{\circ} \mathrm{C}$ for $90 \mathrm{~s}$, then $52^{\circ} \mathrm{C}$ (cyanobacterial primer) for $30 \mathrm{~s}$ and at $59^{\circ} \mathrm{C}$ (primer for $m y c E$ ) for $90 \mathrm{~s}$, after that the temperature was raised to $72^{\circ} \mathrm{C}$ for $60 \mathrm{~s}$ as well as one final cycle at $72^{\circ} \mathrm{C}$ for $8 \mathrm{~min}$. PCR product $(10 \mu \mathrm{l})$ was separated in agarose gel $(1.5 \%)$ using gel electrophoresis stained with ethidum bromide and viewed via a UV transilluminator, the products were compared with the $100 \mathrm{pb}$ DNA marker to estimate their sizes.

\section{Results and Discussion \\ Detection of Cyanobacteria by PCR Technique}

Identification of cyanobacteria through molecular methods is essential for rapid and accurate test for cyanobacterial members. The cpcBA-IGS part of phycocyanin operon was amplified enhancing the existence of DNA from cyanobacteria in freshwater and bloom in sites under study.

Neilan and his coworkers [11] found that a specific band was formed from environmental and cyanobacterial extracted DNA giving a size between 630-700 bp, Cyanobacterial strains produced amplification fragments that ranged between approximately 740 and 500 $\mathrm{bp}$, with the majority of strains providing 700 bp products.

\section{Detection of Microsystin by PCR Technique}

Specific primers for microsystin/ nodularin detection (HEP) were successfully amplified approximately the $472 \mathrm{bp}$ fragments of $m c y E$ gene in both freshwater and bloom samples as shown in Fig. (2).

The HEP primers intended by Jungblut and Neilan [10] were utilized for detection of both 
the $m c y$ and $n d a$ gene clusters in a range of hepatotoxic strains. The primers targeted the aminotransferase domain in the $m c y E$ /ndaF gene for microcystin and nodularin [13]. The PCR assay results of this study revealed that $m c y E$ gene was detected in the bloom and freshwater samples at the three sites under study as shown in Table (1).
As to nodularin, this cyanotoxin is secreated only from Nodularia spumigena and this alga presents in brackish water not listed in Iraqi freshwater.

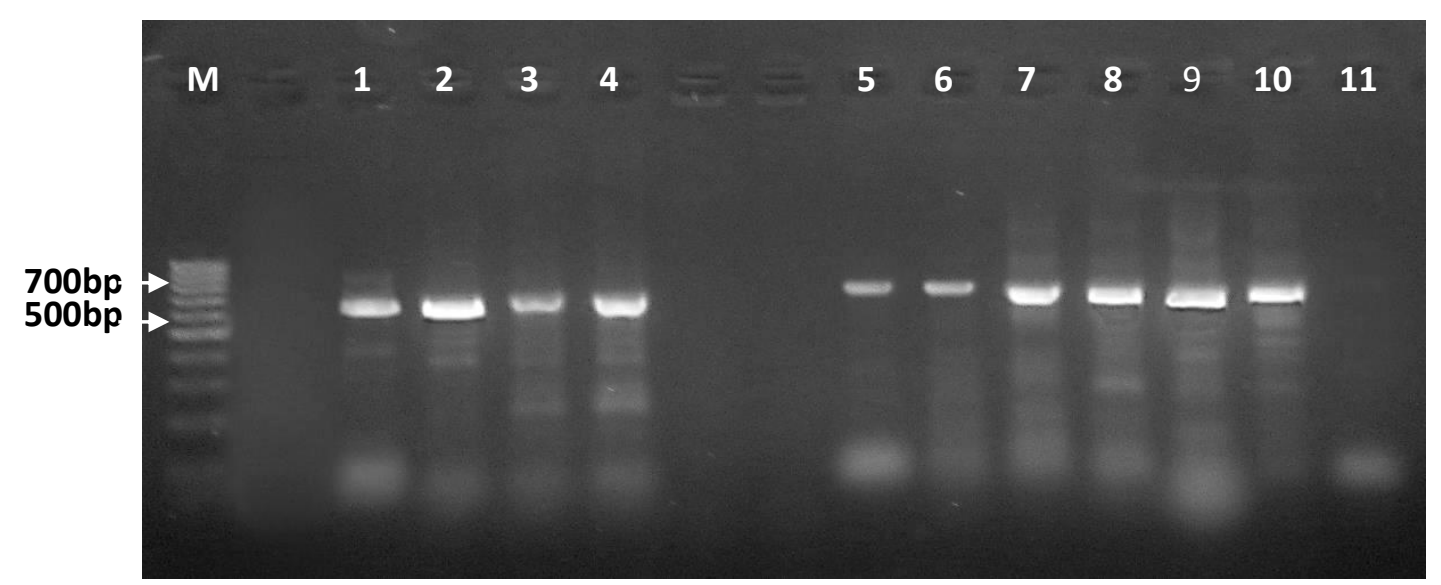

Fig.(1): cpcB-IGS-cpcA (630-700bp) amplification fragment in fresh water, bloom and isolates of some cyanobacteria. Agarose stained with ethidum bromide (1.5\%), $5 \mathrm{~V} / \mathrm{cm}$ for $2 \mathrm{~h}$. M. DNA marker (100 bp). Lane 1-2: Microcystis aeruginosa, Lane 3: Microcystis flos-aquqae, Lane 4: Anabaena sp. Lane 5-7: fresh water samples. Lane 8-10: Bloom samples. Lane 11: Negative control.

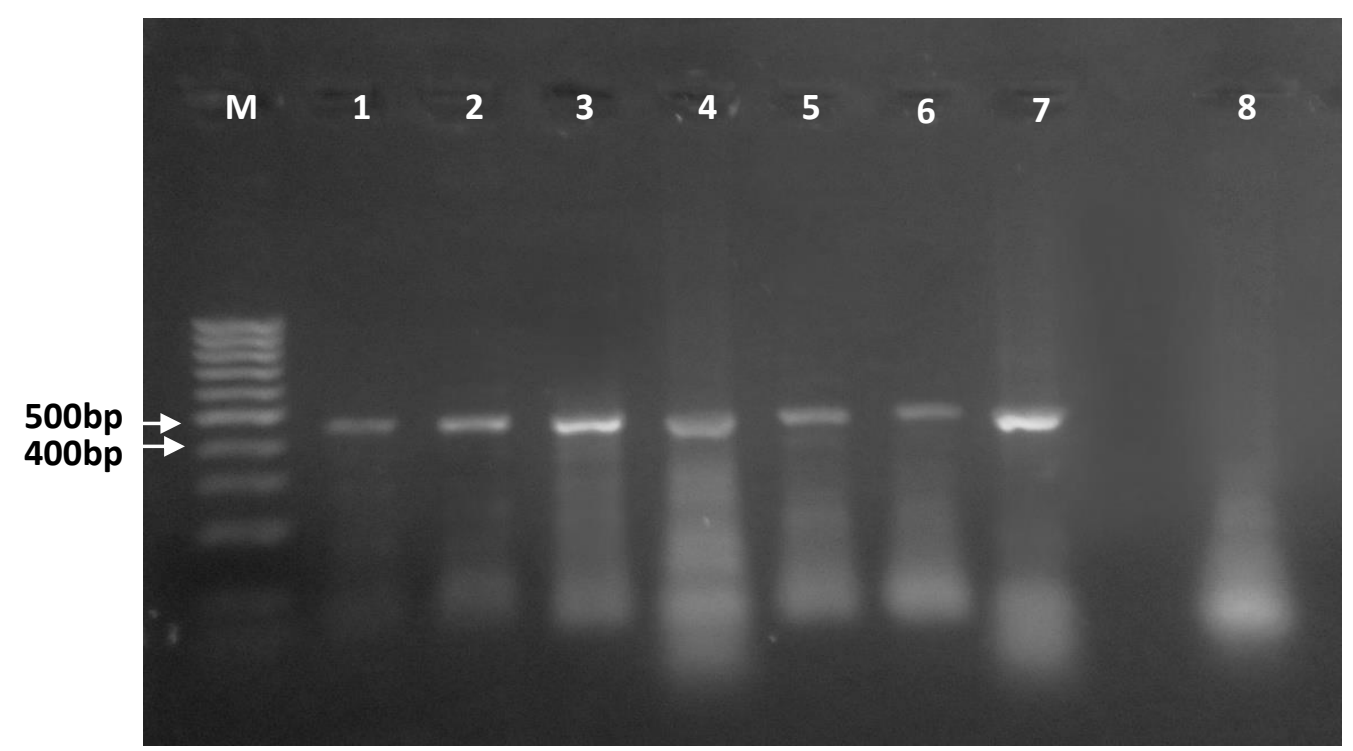

Fig.(2): mycE (approximately 472bp) amplification band in fresh water, bloom and Microcystis aeruginosa. Agarose stained with ethidum bromide (1.5\%), $5 \mathrm{~V} / \mathrm{cm}$ for $2 \mathrm{~h}$. M: DNA marker (100 bp). Lane 1-3: fresh water samples. Lane 4-6: Bloom samples. Lane 7: Microcystis aeruginosa. Lane 8: Negative control.

The PCR technique utilized in present study was found to be quick test, specifically when the target organism number is very low in the freshwater sample; thereby this technique will be helpful for monitoring the formation and progression of microcystin producing cyanobacterial blooms in Iraqi fresh water.

\section{Conclusion}

Results of the current study proved that the toxigenicity of cyanobacterial blooms and 
freshwater can be detected based on the presence of $m c y E$ gene encoding to microcystin. Additionally, the identification of cyanobacteria by PCR technique was done in this study based on the detection of $c p c B-I G S$ $c p c A$ region in phycocyanin operon. This method is beneficial for monitoring the formation of microcystin in blooms produced by cyanobacteria in Iraqi fresh water/ Tigris River.

Table (1)

Amplification state of microcystin in bloom and freshwater samples.

\begin{tabular}{|c||c|c||c|}
\hline Sample & Site 1 & Site 2 & Site 3 \\
\hline \hline Bloom & + & + & + \\
\hline Freshwater & + & + & + \\
\hline
\end{tabular}

(-): no product of PCR.

$(+)$ : presence PCR product.

\section{References}

[1] Hudnell H.K., Dortch Q., Zenick, H. "Overview - chapter 1: an overview of the interagency, International Symposium on Cyanobacterial harmful algal blooms (Isoc-Hab): Advancing the Scientific Understanding Of Freshwater Harmful Algal Blooms" In: Hudnell, H.K. (Ed.), Advances in Experimental Medicine and Biology. Springer, pp.1-16. 2008.

[2] Paerl H.W., Huisman J.. Climate. "Blooms like it hot". New York, N.Y. Science 320 (5872): 57-58, 2008.

[3] Abed I.J. "PCR- Based Test for the Early Warning of Both Cylindrospermopsin and Saxitoxin in Iraqi Freshwater". Journal of Al-Nahrain University, 18 (3) pp:109-114, 2015.

[4] Turner A.D., Dhanji-Rapkova M., O’Neill A., Coates L., Lewis A.and Lewis K. "Analysis of Microcystins in Cyanobacterial Blooms from Freshwater Bodies in England", Toxins, 10 (39):2-29, 2018.

[5] Azevedo S.M., Carmichael W.W., Jochimsen E.M., Rinehart K.L., Lau S., Shaw G.R., Eaglesham G.K. "Human intoxication by microcystins during renal dialysis treatment in Caruaru-Brazil”. Toxicology 181-182, 441-446, 2002.

[6] World Health Organization (WHO). Guidelines for Drinking-Water Quality:
Fourth Edition Incorporating the First Addendum; WHO: Geneva, Switzerland, 2017.

[7] Mazur-Marzec H., Bertos-Fortis M., nskaSitarz A., Fidor A. and Legrand C. "Chemical and Genetic Diversity of Nodularia spumigena from the Baltic Sea". Mar. Drugs, 14 (209): 2-14, 2016.

[8] Akcaalan R., Marzur-Marzec H. and Albay M. "Phenotypic and toxicological characterization of toxic Nodularia spumigena from a freshwater lake in Turkey”. Harmful Algae, 8: 273-278, 278.

[9] Lajeunessea A., Seguraa P. A., Gelinasa M. Hudona C., Thomasb K., Quilliamb M. A. Gagnona, C. "Detection and confirmation of saxitoxin analogues in freshwater benthic Lyngbya wollei algae collected in the St. Lawrence River (Canada) by liquid chromatographytandem mass spectrometry". Journal of Chromatography A, 12(19): 93-103, 2012.

[10] Matehkolaei A.R, Makimura K., Shidfar M.R., Zaini F., Eshraghian M.R, Jalaizand N., Sisakht S.N., Hosseinpour L., Merhendi H. "Use of single-enzyme PCRrestriction digestion barcode targeting the internal transcribed spacers (ITS rDNA) to identify Dermatophyte Species". Iranian J. Publ. Health, 41(3): 82-94, 2012.

[11] Neilan B.A., Jacobs D. and Goodman A.E. "Genetic diversity and phylogeny of toxic cyanobacteria determined by DNA polymorphisms within the phycocyanin locus". Appl Environ Microbiol. Nov; 61(11):3875-83, 1995.

[12] Jungblut A.D. and Neilan B.A. "Molecular identification and evolution of the cyclic peptide hepatotoxins, microcystin and nodularin, synthetase genes in three orders of cyanobacteria". Archives of Microbiology,185: 107-114, 2006.

[13] Moffitt M.C. and Neilan B.A. "Characterization of the Nodularin Synthtase Gene Cluster and Cyanobacterial Hepatotoxins". Appl. Environ. Microbiol.; 70(11): 6353-6362, 2004. 